\title{
A Study on Improving ESP English Reading Ability for Students Major in Mechanical Design and Manufacturing
}

\author{
Juan $\mathrm{Du}^{1 *}$ \\ ${ }^{1}$ College of Language and Literature, Lijiang College of Guangxi Normal University, Guilin, Guangxi, China
}

Correspondence: Juan Du*, College of Language and Literature, Lijiang College of Guangxi Normal University, Yanzhong Road, Yanshan Town, Guilin, Guangxi, China. E-mail: dujuan@gxljc.edu.cn

\begin{abstract}
ESP Teaching method is an approach that is significantly different from the conventional English Language Teaching method. ESP teaching is a market-driven, communicative English teaching model which is based on the overall principle of significantly improving learners' professional English social skills, learnercentered, and meets the needs of society and individuals. In this study, researcher's attempt is to integrate ESP reading model into the design and manufacturing English teaching. The study aims to explores the effect of ESP reading in mechanical design and manufacturing English teaching from the following three points, preclass reading task detection, while-reading teaching and post-reading teaching. And the author finds that ESP reading model not only make students have a strong interest in English learning and reading, improve their English reading ability and application ability of professional knowledge, but also enhance their innovative thinking ability.
\end{abstract}

\section{Introduction}

With the globalization of the world economy and the integration of science and technology, "English learning in the future is no longer just English learning", "English teaching in the future is increasingly combined with a certain professional knowledge or a certain subject", and ESP teaching will become the mainstream of English teaching in the 21st century (Liu Runqing, 1996). The English teaching model of some universities in Hong Kong proves that providing English for Special Purpose (ESP) courses for students with a certain foundation, including various professional courses offered in English to replace the compulsory basic English, will not affect students' English improvement, but also promote the efficiency of language learning (Cai Jigang, 2004). The purpose of English teaching in China's ordinary higher engineering colleges is to enable students to use English as an auxiliary tool, so as to learn more professional knowledge, master the latest trends in the industry, and improve their professional skills and potential employability. At present, in many universities in China, English teaching for non-English majors is divided into English for General Purpose (EGP) and English for Special Purpose (ESP). However, many students don't have much awareness of strengthening the application ability of professional English, which leads to their inability to read professional articles and their professional reading ability can't meet the needs of professional communication. Students' limited professional English reading skills not only seriously hinder the development of their English application ability, but also hinder their employment potential, which makes the talent training in colleges and universities deviate from the social talent demand standards. At the same time, a large number of students have become accustomed to intensive reading and slow reading of English articles after learning public English, while the reading purpose of ESP requires students to read for quick access to information. ESP teaching materials not only involve a large number of technical terms and professional knowledge, but also have a long text, which brings great challenges to students' English reading ability, and many senior college students cannot read relevant professional materials. In view of the present situation, it is an urgent problem to improve students' ESP reading ability.

English reading teaching for mechanical design and manufacturing is an important part of English teaching. As a branch of ESP reading teaching, it has its own language characteristics. On the one hand, reading English for mechanical design and manufacturing enables students to master relevant reading skills, improve reading speed and expand relevant vocabulary of professional English through reading materials related to mechanical design and manufacturing. On the other hand, reading specialized English is an important way to impart knowledge of mechanical design and manufacturing, which can provide a lot of rich materials for students to learn specialized English, broaden their knowledge and professional perspective, and enrich their professional knowledge. The language characteristics of English reading for mechanical 
design and manufacturing can be summarized as follows: professional vocabulary and trade terms emerge in endlessly, reading materials contain a large number of professional scientific and technological vocabulary, and most of them adopt formulaic expressions; In the aspect of language use, passive voice, unqualified verbs and commonly used conditional sentences, long sentences and ellipsis sentences are often used.There is no doubt that English reading for mechanical design and manufacturing is different from English reading, which is related but different. The most prominent difference is that English reading for mechanical design and manufacturing involves a wide range of professional knowledge, vocabulary and terminology. Admittedly, English reading teaching for mechanical design and manufacturing specialty must not adopt the same mode and means as English reading teaching, otherwise, it will not achieve the purpose of English reading teaching for mechanical design and manufacturing specialty.

\section{Study Purpose and Method}

ESP, the abbreviation of English for Specific Purposes, was put forward by Halliday (Halliday,1964: 50) in1964. $\mathrm{He}$ considers that English should have its own characteristics and usage rules for a certain industry and field of society. The emergence of ESP theory is both the social need for English language use and the result derived from the functionalist view of language. ESP teaching is a market-driven, communicative English teaching model which is based on the overall principle of significantly improving learners' professional English social skills, learner-centered, and meets the needs of society and individuals. The purpose is to help learners master the English skills of effective communication in the professional field. ESP teaching mode can combine basic English teaching with vocational education, English language teaching with professional technology, so as to further enhance students' interest in learning English, promote cultural awareness and improve professional accomplishment. Giving full play to the professionalism and practicability of English teaching, it has remarkable practical value in cultivating applied talents in higher vocational English teaching.

The purpose of the study:

The study aims to check the effect of ESP reading in mechanical design and manufacturing English teaching.

The research questions

The present study aims to answer the following two questions:

Can ESP reading improve the enthusiasm of students' professional English learning and their professional English application ability?

How does ESP reading improve the effectiveness of English teaching for students major in Mechanical Design and Manufacturing?

\section{Results and Discussions}

In view of the above problems, the author explores the effect of ESP reading in mechanical design and manufacturing English teaching from the following three points: pre-class reading task detection, while-reading teaching and post-reading teaching.

\subsection{Pre-class Reading Task Detection}

Although English reading for mechanical design and manufacturing is a branch of traditional English reading, the obvious difference from traditional reading lies in the concentrated presentation of professional knowledge of mechanical design and manufacturing. It is important for teachers to explain English vocabulary, grammar and text interpretation in class, but the study of mechanical design and manufacturing expertise should be the top priority of English reading course. Teachers assign learning tasks at the beginning of the semester, group students, and let students find information, discuss in groups and cooperate to complete topic presentation reports; After each group completes the report, the teacher give some evaluation on their performance, which make the students have a better understanding of the material they report and also bring some confidence and interests in special English learning . Through pre-class preparation, students have a deeper understanding of the topics discussed, which not only aroused their interest in language learning, but also deepened their learning of the professional knowledge. Pre-class task detection based on professional knowledge makes students no longer think that reading teaching is just listening to teachers who explain vocabulary and articles as usual, but really integrated into specific professional knowledge learning, which embodies the principle that ESP reading teaching content meets learners' specific needs.

\subsection{While-reading Teaching}

In the process of English reading teaching at the present stage, most teachers often regard the text as a language material, and most of the time let students study English vocabulary, grammar and sentence patterns through the text, which makes many students pay attention only to vocabulary, phrases and sentence patterns. The neglect of the meaning of the material leads to a result that there is no purpose in reading, and the reading comprehension ability of the students is poor, especially the ability of reasoning, judgment and induction. In fact, the purpose of reading teaching is to train students to master the reading methods and skills from the whole article, and gradually acquire the ability of independent reading. Discourse teaching is an important way to improve students' reading comprehension ability, cultivate students' language application ability and improve students' overall English quality. Discourse teaching belongs to the category of functional idealization teaching, which aims to train students to understand the author's viewpoint and writing intention, so as to master the ability of reading the whole text. In the process of reading teaching, teachers should guide students to understand the theme of the text, analyze the text patterns, and grasp the content, theme, author's viewpoint, attitude and intention of the text from the key words, central sentences and paragraphs of the article. 
Teaching focuses on "articles" rather than "sentences", and on "gist" rather than "language analysis". Classroom reading activities should start with the analysis of theme, text structure and paragraph cohesion, and teachers should guide students to pay attention to understanding the author's central idea and text structure. In the continuous reading process, they should grasp the specific structure of relevant reading models and improve their overall understanding and grasp of the article. There are several ways to understand the central idea of discourse and long and difficult sentences and words in the following.

The summary of the central idea can be carried out from the following aspects:

1) Focusing on the title of the article.

2) Focusing on the central sentence of the article or the topic sentence of the paragraphs.

3) Focusing on the cohesive sentences and paragraphs of the article.

4) Focusing on the beginning and the end of the article.

5) Focusing on lyrical and argumentative sentences.

Understanding of long and difficult sentences and words can be carried out from the following aspects:

A. Understanding it with key words

B. Understanding it with contextual connection

C. Understanding it with rhetorical devices

D. Understanding it from the background of the times

E. Understanding it with analyzing the levels of sentences

Teachers play a leading role in the classroom, guiding students to understand reading material from shallow to deep. After students master the background knowledge of the article, the central idea of the article and the structure of the article, teachers can carefully design some questions to guide students to read and analyze independently based on the content of the article. The design of questions should integrate the key contents of the article, so that students can accurately grasp the central idea conveyed by the article in the specific process of answering questions. The improvement of reading ability is actually a very complicated training process of comprehensive ability. Teachers should pay attention to the analysis of article structure, introduce and explain various article structures and characteristics to students. He can also train students to use titles, discourse markers and key sentences to identify the structure of the article, which can make students know clearly the logical connection between sentences and paragraphs and further strengthen the understanding of the theme and the structure of the article. This will not only provide an interesting reading platform for college students, but also enhance their comprehensive application level of knowledge and skills.

\subsection{Post-reading Teaching}

After class, teachers can show students background pictures and videos closely related to English reading articles through multimedia, or share a humorous performance, which can arouse students' desire and interest in English reading, and make students take the initiative to further read and learn more knowledge related to the contents of articles. In addition, creating situations can describe the content of the article by means of roleplaying, group discussion and imagination. Creating a relaxed and pleasant classroom learning situation is conducive to stimulating students' reading interest, broadening students' English reading interest and improving their language use ability.

In English reading teaching, there is a kind of cramming teaching which is mainly taught by the teacher, which leads to students' low participation, low reading interest, and lack of interest in class and after class. The main reason for this kind of cramming teaching is that teachers teach reading knowledge out of context and just focus on the explanation of the text, which makes students lack of thorough and comprehensive understanding of reading material. Situational teaching method aims to return the initiative of learning to the students and fully respect the students' dominant position. Teachers set up teaching activities that are really close to students' life according to the reading contents and teaching tasks of professional English, so that students can have something to say, want to say, know how to say, and actively participate in the teaching activities. By setting a scene for students to play different roles and learn specialized English reading course in pleasant role experience games, students can not only have a deeper understanding of the teaching materials, but also enhance and improve their language ability and stimulate their enthusiasm and interest in learning. Teachers can also show students background pictures and videos closely related to reading articles in English through multimedia, or perform a humorous performance to arouse students' desire and interest in English reading, so that students can take the initiative to further reading and learn more knowledge related to the contents of articles. In addition, creating situations can describe the content of the article by means of role-playing, group discussion and imagination. Creating a relaxed and pleasant classroom learning situation is conducive to increasing students' interest in English reading, attracting students' attention, broadening students' interest in English reading and improving their language proficiency. In this process, teachers cultivate students' interest in English reading with appreciation, guide and enhance students' ability to solve problems independently, learn independently and think logically, and at the same time create a relaxed and happy learning environment to improve students' professional English reading comprehension.

Effective teaching and reading largely depends on teachers' teaching methods and teaching atmosphere. Firstly, a good teaching atmosphere can arouse students' interest and enthusiasm, and then introduce the learned knowledge into the classroom. Teachers can create different reading situations for students according to the contents of teaching materials, and help students to read actively, instead of just being a bystander. Teachers can stimulate students' curiosity and thirst for knowledge and arouse students' thinking according to their knowledge level when creating problem scenarios. Secondly, in situational teaching, the questions raised by teachers should be hierarchical, not too difficult, or exceed the students' ability to understand and accept. After discussion, students will get a lot of knowledge over textbooks, which 
not only completes the text knowledge, but also enables students to sum up. Situational teaching method can help teachers simulate the real situations needed for teaching, create different reading situations, activate students' brains, cultivate students' innovative thinking ability, arouse students' enthusiasm for English reading, stimulate students' interest in learning to the maximum extent, improve their English reading ability, and finally achieve the teaching objectives.

\section{Conclusion}

Consciousness is the leading factor of behavior. Only when teachers change their subjective consciousness can English reading teaching become student-centered and also be effectively implemented. From the essence of teaching, teaching activities are a kind of knowledge transfer phenomenon produced by effective communication between teachers and students. The focus of education is not on teachers' "imparting knowledge", but on students' independent exploration of knowledge. Based on the analysis of the learning status of mechanical English for some college students, this paper explores the effect of ESP reading in mechanical design and manufacturing English teaching from the following three points: pre-class reading task detection, while-reading teaching and post-reading teaching. To sum up, it is necessary to strengthen the teaching of ESP reading course and improve students' ESP reading ability due to the improvement of college students' professional English application ability. Not only can students have a strong interest in English learning and reading, improve their English reading ability and application ability of professional knowledge, but also enhance their innovative thinking ability, so that students can obtain comprehensive development in their English learning.

\section{References}

1. Cai Jigang. ESP and the Development Direction of College English Teaching in China[J]. Foreign Languages, 2004 (2) 22-28.

2. Du Juan. English Applied Ability Teaching Reform of Mechanical Design and Manufacturing in ESP Teaching Mode[J]. Journal of Physics: Conference Series, 2021, 1820(1) : 012017-.

3. Halliday, M. A. K. , Macintosh, A. \& Strevens, P. The Linguistic Sciences and Language Teaching [M]. Shanghai: Shanghai Foreign Language Education Press, 1964.

4. Liu Runqing. English Teaching in the 21st Century-a Survey in Britain [J]. Foreign Language Teaching and Research, 1996, (2).

5. Peng Yan. Strengthening the Teaching of ESP Reading Course in Universities [J]. Science and Technology Information, 2011(02):190-191. 